\title{
Tax Secrecy and its Limitations: Is There a Balance? ${ }^{1}$
}

\author{
Tereza Rogić Lugarić \\ University of Zagreb, Faculty of Law, Croatia \\ tlugaric@pravo.hr \\ Irena Klemenčić \\ Institute of Public Finance, Zagreb, Croatia \\ irena.klemencic@ijf.hr
}

\section{ABSTRACT}

Economic development in the past decades and the increase of crossborder business by the multinationals coupled with recent financial crisis have brought many questions about whether the taxpayers are paying their fair share. In order to assess the equitable amount of taxes due, revenue authorities often rely on information provided to them by taxpayers. In conducting their procedures, revenue authorities are in principle bound by tax secrecy. However, recently, the tax systems have introduced tax policy instruments with opposing effects, intended to provide full insight in taxpayers' revenues worldwide and affect the taxpayers' behaviour towards greater tax compliance. Two such instruments are particularly worth noting, public shaming lists, used primarily nationally, and international exchange of information, as a cross-border procedure. Through comparative legal approach we provide an analysis of legal instruments balancing tax confidentiality and tax transparency. As the research will show, the optimal level of tax secrecy, while preserving international standards of tax transparency, is very difficult, if not impossible, to accomplish. Legal tradition of secrecy, implementation of international standards and the evaluation on the adequacy of such measures should all be taken into account before jumping to any conclusions about the perfect balance. The goal of accomplishing fair and equitable tax system must not be disregarded as well.

Keywords: tax secrecy, tax transparency, public shaming lists, exchange of information

$J E L: K 34$

1 This article is a revised version of the paper entitled 'Tax Secrecy and Its Limitations: Is There a Perfect Balance?', presented at the EGPA conference, Milano, 30 August-1 September 2017. The EGPA contributions are not publically available. 


\section{Introduction}

The concepts of secrecy, privacy and transparency are more topical and pertinent in contemporary societies than ever before. In taxation, they are related to two crucial questions - how revenue authorities administrate taxes and whether taxpayers fulfil their tax obligations. While conducting tax procedures, revenue authorities are in principle bound by tax secrecy, a principle designed to protect "glass taxpayers" and, consequently, result in greater tax revenues by encouraging tax compliance. Recently, tax systems have introduced tax policy instruments with opposing effects, calling for more tax transparency, meant to provide full insight in taxpayers' revenues worldwide and affect taxpayers' behaviour towards greater (voluntary) tax compliance. Therefore, the main issue is whether and to what extent should tax information and related documents be public or confidential.

Despite the current lively debate on the prevailing concept of gathering and disclosing tax information, there is insufficient empirical and theoretical research in this area. There is preliminary evidence that a loss of confidentiality increases compliance (Laury \& Wallace 2005). Blaufus, Bob and Otto (2014) concluded that general public disclosure could result in more, instead of less, evasion leading to two possible effects of tax publicity - the shame effect and the contagion effect. Perez - Truglia and Troiano (2015) analysed shaming policies as a tool to improve tax debt collection. They demonstrated that the optimal policy might be a combination of financial and shaming penalties. Schenk-Geers (2009) examines international exchange of information from a taxpayers' viewpoint. Hambre (2015) deals with comparative analysis of tax transparency and assesses impacts of tax compliance, administrative costs and taxpayer privacy.

Public shaming is in line with the new theories about tax regulation and tax compliance which take into account social and personal standards as factors influencing a specific type of behaviour. This instrument is used as means of deterring aggressive tax planning as well as preventing tax enforcement and raising awareness of (voluntary) tax compliance. The comparative analysis of countries with the tradition of tax privacy and those strongly adhering to tax transparency may lead to opposing conclusions about the usefulness and adequacy of this instrument. The international exchange of information has been the headline of tax policy debates, and recently the automatic exchange of information was introduced as the new global standard. Its main purpose is to provide tax administrations with sufficient information to fully meet the standard of worldwide taxation and to leave no income untaxed, while avoiding double taxation. Also, the two instruments have been chosen to provide insight into national as well as international measures.

The principle method used in this paper is a comparative legal analysis of different approaches to balancing tax confidentiality and tax transparency, trying to identify certain divergences and convergences in the systems selected. In this regard, the U.S., Croatian, French, German and Swedish systems were selected for the purpose of this paper. Additional factors were taken into 
consideration when choosing the systems mentioned. One of the factors was affiliation with different tax-law families. U.S., French and German systems were chosen as leaders influencing tax law in other countries.

The analysis will focus on two main research objectives. Firstly, it aims at defining the key components of tax secrecy model, its development and provide examples of best practices of its implementation in selected countries. However, as lately the use of some tax policy instruments have infringed tax secre$c y$, we examine the influence of shaming lists and exchange of information as its opposing tax policy instruments in the aspiration of achieving the ultimate goal: the equitable and balanced tax system efficiently providing the highest possible level of tax revenues.

\section{Tax Secrecy - Main Features and Issues}

Tax secrecy is cited as one of the main general tax principles and basic taxpayers' rights although its meaning, content and wording is not uniformly defined (e.g. European Commission 2016; OECD 2003; Bentley 2007). Traditionally, the principle of tax secrecy was introduced to encourage taxpayers' participation in tax procedures. It was believed that taxpayers would be more comfortable with the idea of cooperation and disclosure of all facts if they believe in the discretion of tax officials, i.e. this would foster (voluntary) tax compliance and serve as a sort of counterbalance to tax administrations' (broader and broader) powers in collecting tax information. Generally, the concept of tax secrecy confronts often opposite interests of taxpayers on the one side and revenue authorities on the other.

When we summarise its various definitions, three common elements could be identified: (i) tax administrations ${ }^{2}$ should protect taxpayers' private information, as well as all other information about a particular taxpayer that becomes available to them during tax procedures, from unauthorised use and disclosure; (ii) exceptions from tax secrecy (i.e. cases which do not constitute violation of the tax secrecy principle) should be specified in tax regulations; and (iii) disciplinary accountability and/or criminal liability is held against those (tax) officials who breach tax secrecy and misuse protected information.

Over the past few decades the area of tax secrecy has been very dynamic. Undoubtedly, main challenges faced by contemporary tax administrations voluntary tax compliance, fighting tax avoidance among others - prompted some sort of review of the role and meaning of tax secrecy in contemporary tax systems. Keeping that in mind, tax secrecy has become an issue in national as well as in international tax law. In a national environment, the question of the influence of tax secrecy on (voluntary) tax compliance was (partly) provoked by the emergence of the concept of paying taxes as a "civic virtue" that particularly gained importance towards the end of the $20^{\text {th }}$ century, also in

2 And all other official persons involved in tax procedures, e.g. different experts engaged by revenue authorities. 
the context of ensuing theoretical (r)evolution. ${ }^{3}$ Questions have been raised as to whether (at all) and if so, to what extent tax secrecy could be used in ways "that do not only evoke deterrence but rather create trust and promote social norms" (Hambre 2015, p. 63) or whether it is time to replace it with the opposite concept of tax transparency.

Another challenge for revenue authorities has emerged recently through rapid development of tax information exchange instrument. Although the exchange of information has been in used since $19^{\text {th }}$ century (Oberson 2015, p. 4), and it has been a standard part of tax treaties worldwide, in the past decade this instrument has been much discussed by the tax law community. In tackling aggressive tax planning, harmful tax regimes and tax evasion, often caused by lack of information, countries can engage in tighter cooperation to increase the amount of information at their disposal (Remeur 2015, p. 16). The development of the exchange of information, and in particular, recent rapid acceptance of automatic exchange of information as the new global standard has brought about the issues of breaches of confidentiality, priva$c y$, secrecy and abuse of data exchanged to the highlight of global tax policy agenda (Oberson 2015, p. 209).

Recently, in 2016, the EU General Data Protection Regulation (GDPR) has been adopted and will come into effect on 25 May 2018, replacing the EU Data Protection Directive. The GDPR is a regulation, binding in its entirety and directly applicable in the EU member states. Briefly, GDPR represents a major change in the protection of (taxpayers') personal data as it provides for a stronger protection of individuals' privacy, imposes increased obligations on legal entities regarding collection and processing of personal data and introduces significant penalties for breaking the rules. GDPR considers protection of personal data as legislative objective, a part of fundamental freedoms and rights, unlike the Directive which only refers to the right to privacy instead (Huang, 2018, p. 237). This development has put the matters of data protection high on the public policy agenda, especially as it relates to the sensitive taxpayer information and revenue authorities among other institutions are subject to its provisions. In a more general sense it seems that this normative development could be seen as a way of balancing current trends towards tax transparency with the protection of "glass" taxpayers.

\subsection{Comparative Models}

Based on the comparative analysis, heterogeneity of the models can be observed when it comes to a legal approach to disclosing taxpayers' information. In general, three models regarding its main rule and starting point can be identified: (i) an "unlimited" model of tax secrecy; (ii) a hybrid or limited model of tax secrecy; and (iii) a tax transparency model.

(i) The most prominent representative of the first model is the German one. It is described as a model strongly adhering to tax secrecy - unlike other mod-

3 New theories of (tax) regulation and tax compliance have been emerging. They primarily seek to understand, explain and even predict taxpayers' behaviour in relation to government. 
els, tax secrecy has a constitutional origin and base (see also Valta 2013). ${ }^{4}$ According to the Fiscal Code of Germany (Abgabenordnung, hereinafter AO), all information and circumstances of a third person which have become known to tax officials (and other persons of equivalent status to public officials) in tax-related procedures are protected by the institute of tax secrecy. It does not matter whether this information is tax relevant - tax secrecy refers to all personal, economic, public or private relationships of a certain, legal or natural, person.

(ii) The second model is considered a hybrid or rather a limited model of tax secrecy. The secrecy principle prevails, however, it implies a certain degree of "tax publicity." The French, U.S. and Croatian models could be included in this group. In the French model, tax secrecy is, similar to the German model, seen as a mechanism of taxpayers' privacy protection, however with certain limitations. Therefore, unlike Germany, tax secrecy in this model has no constitutional origin although it is declared by the Taxpayers' Charter as a value. It is understood as "professional" secrecy (sections L. 103. - L. 167. A LPF") and the obligation to keep it, under the provisions of the Criminal Code ${ }^{6}$, applies to all persons involved in various procedures related to taxes and other public duties ${ }^{7}$ and concerns all information collected in the course of these procedures. However, it seems that the professional secrecy obligation for tax officials is understood and regulated more stringently than for other public officials (Dubut 2013, p. 417). The professional secrecy obligation and protection of taxpayers' private lives are especially emphasised in the tax audit procedure (section L. 103 subsection 2 LPF). The rules on professional secrecy also include rules for the delivery of documents to taxpayers (section L. 104 - L. 111 LPF). Regarding tax secrecy "limitations", two such groups of cases can be identified. The first one is covered by the term "public interest" and the second group of "limitations" concerns "tax publicity" (section L. 111 LPF).

When it comes to the principle of tax secrecy in the United States, a number of main issues could be mentioned. First of all, the question of confidentiality in tax matters includes the question of tax return publicity and public access to those documents. American history has known alternations of different periods of legal regulation of this matter that were followed or preceded by lively (public) debates between advocates of tax privacy, on the one hand, and advocates of tax transparency, on the other hand. One of the main reasons for the mentioned debate, as well as for different regulation of tax confidentiality through history, is its influence on voluntary tax compliance. Both sides have been using the same argument, i.e. that the prevailing concept of tax privacy or tax transparency would have a significant role in encouraging voluntary tax compliance and preventing tax evasion, however supporting it with different explanations. Advocates of tax privacy highlighted that tax returns contain a large quantity of private and sensitive information. There-

4 The base is a constitutional right to informational self-determination.

5 Livre des procédures fiscales (The Law on Tax Procedures).

6 It sanctions all violations of professional secrecy. The sanctions provided are monetary fines and one-year imprisonment.

7 Meaning tax assessment, tax audit, tax collection etc. 
fore, taxpayers would be (more) compliant if they believed in the revenue authorities' honesty and discretion. Advocates of tax transparency emphasise a possible influence of tax transparency on the change of otherwise private and/or hidden behaviour as the main argument, using this concept as a kind of supervision. They believe that, among others, public access to tax returns and tax information "would shame the affluent into heightened compliance with their tax obligations" (Harrison in Schwartz, 2008, p. 891). As new theories on tax compliance and tax regulation have been emerging, the debate has been continuing especially "when government seeks innovative ways to address tax gap" (Blank 2013, p. 1).

The year 1976 was somewhat of a milestone in legal regulation since the Tax Reform Act, for the first time, "enacted a comprehensive statutory scheme regulating the use and disclosure of tax returns and tax return information" (Department of the Treasury 2000, p. 22). The four main rules established then have remained in force until today. The general rule is that returns and return information are confidential and, except as authorised in the Code, may not be disclosed by an officer or employee of the United States, or an officer or employee or any State or other person who has had access to returns or return information (s. 26 United States Code, section 6103). ${ }^{8}$ Exceptions from general tax confidentiality, although thoroughly prescribed, are actually numerous and, for the most part, could be justified on the grounds of public interest as well as potential new threats (e.g. terrorism).

The role model for the Croatian tax secrecy regime was the German model, ${ }^{9}$ which is especially visible in the fact that it has a constitutional origin. However, unlike Germany, certain features of the Croatian model were regulated very vaguely from the beginning. This refers to the exact meaning of "unauthorised use or disclosure" (as opposed to a very detailed explanation of the concept in German tax law) or the definition of what type of information is covered by tax secrecy (e.g. tax relevant or not). With time, the main legal scheme has changed in two directions: (1) expanding cases that do not constitute a violation of tax secrecy and (2) introducing tax publicity, namely shaming lists, which brought the Croatian model into this group. Although cases where the obligation of tax secrecy is not violated are not numerous and mainly include standard solutions (a written consent of the persons concerned) or could be justified on the grounds of administrative efficiency (e.g. cooperation with other public bodies, or administrative cooperation in the field of taxes), some of these cases are prescribed very generally. ${ }^{10}$

(iii) Probably the most "open" system among the systems analysed here is the Swedish model since its "starting point" is considerably different. The law governing the Swedish tax secrecy model is the Public Access to Information

8 The taxpayer's right to confidentiality is also guaranteed by the Taxpayer Bill of Rights, adopted in 2014.

9 The same holds true for tax law in general, bearing in mind that the Croatian tax system is quite young due to the socialist system existing until 1990.

10 E.g. if the data are disclosed for the purpose of tax enforcement procedures (section 8 subsection 5 number 5 General Tax Code), which might actually be a number of cases. 
and Secrecy Act (hereinafter PAISA) enacted in 2009. The principle of public access to information means that the public and mass media are entitled to receive information on state and municipal activities. It comprises, among others, access to official documents; freedom of expression for officials and others; right to communicate and publish information (Ministry of Justice 2009, p. 7). The Act also includes provisions on secrecy which entail "restrictions both on the right of the public to obtain official documents (...) and on the right of public functionaries to freedom of expression" (Ministry of Justice 2009, p. 7), hence it regulates tax secrecy (Chapter 27). The basis for those rules is constitutional law, the Freedom of the Press Act (FPA), which provides for the right of public access to official documents and its possible restrictions (Hambre 2015, p. 165). The main rule in PAISA is that "full secrecy applies to all work within the tax authority that relates to establishing taxes to be paid by individuals and companies while the tax decisions are normally public" (Nergelius 2017, p. 3). In other words, secrecy does not protect the tax return as a document but protects from disclosing the information within (Hambre 2015, p. 166). As tax secrecy provisions do not lay down any special requirements for the applicability of secrecy, we talk about "absolute" secrecy. However, decisions of tax courts and public decisions are another case characterised by "high level of transparency" (Hambre 2015, p. 166). When it comes to tax court proceedings, the secrecy provision here will apply under certain conditions known as the "requirement of damage" which, in general, could be straight or reverse. Therefore, when it comes to taxpayer information in court proceedings, transparency is presumed but the information may be kept secret if it is concluded that disclosure would cause damage to the individual in question (Hambre 2015, p. 166). Even a higher level of transparency is provided for in relation to tax decisions since tax decisions are normally public, according to the PAISA (Chapter 27, Article 6), (Kristofferson, Persson, Nergelius, Valguarnera, Hambre, Larsson, 2013, p. 1079). The law enumerates decisions that are considered to be secret (e.g. decisions on dismissal, advance rulings). Kristoffersson et al. (2013) emphasise that not only tax decisions are public but also the grounds for the decisions, which leaves room for public insight and some sort of public "surveillance" of the revenue authorities' work and performance. Although tax secrecy (or transparency) in Sweden is not directly related to tax compliance, as is the case in the U.S., such a model of "targeted tax transparency" (or better to say "tax secrecy") might have benefits for voluntary tax compliance, especially in terms of enhancing the procedural and retributional fairness of the tax system. On the other hand, it is admitted that it raises serious questions concerning the protection of the taxpayer's privacy (Hambre, 2015; Nergelius, 2017), which also might hinder voluntary tax compliance. However, in this regard, Nergelius (2017, p. 3) conclusion may be very illustrative: "Perhaps this kind of publicity does not exist in so many other countries, but so far, Swedish people have been able to live with it". Moreover, this observation might also explain the small number of individual complaints related to this issue. 


\section{Tax Secrecy Limitations}

Analysis in the previous paragraphs has revealed certain exceptions from the tax secrecy rule. Three such exceptions could be identified. First, a number of derogations could be gathered under the umbrella term of "public interest." The second one covers tax publicity. The third one concerns exchange of information - one of the vehicles of combatting tax evasion.

\subsection{Public Interest}

Public interest is generally considered the "Achilles' heel" of the tax secrecy model (Lang in: Tipke, Lang 2010) creating a kind of a "gap" between the declarative and real meaning of the institute. In the German model, the Code stipulates cases in which disclosure (but not use) of obtained information is permissible (section 30, subsection $4 \mathrm{AO}$ ). One of the most controversial provisions here is "compelling public interest for such disclosure" (subsection 4 number $5 \mathrm{AO}$ ). Analysing the legal wording, it seems that "compelling public interest" is a rather imprecise and vague legal term leaving room for theological and "case by case" interpretation as well as "prone to disproportionate use" (Valta 2013, p. 457). It should also be added that revenue authorities in the cases specified in subsection 4 are (generally) authorised, but not obliged to disclose relevant information. Thus, they can use discretion in cases where they should primarily take into account the purpose of the given authorisation and (existing) statutory restrictions (section $5 \mathrm{AO}$ ). However, in certain cases, revenue authorities are obliged to disclose relevant information (section 31, 31a, 31b AO). Those cases concern, for instance, disclosure to public-law entities, statutory social insurance institutions, disclosure for the purpose of countering unlawful employment or money laundering; in other words, there is (again) a strong public interest and "common good" behind them, giving prominence to the "fiscal role" of revenue authorities. The term "common good" is also used as 'justification' for sections 93 (subsections 7 and 8) and $93 \mathrm{~b} A O$, which regulate automated access to the data. Although those provisions raise a number of issues, the Federal Constitutional Court has declared that they are in conformity with the Constitution, on the grounds of serving the "common good." However, the Court held that these provisions need to be more precise and clear. It seems that (higher) nomotechnical standards are the only possible way for increasing legal certainty and protecting taxpayers. Very similar situation is in other countries. In the French model, the term "public interest" also serves as a justification for a number of derogations from the professional secrecy rule regulated in sections L. 113 - L. 167. A LPF. The law itself divides these derogations into seven groups on the grounds of main beneficiaries, e.g. derogations in cases of international fiscal assistance; derogations in cases of benefit for certain administrative bodies, public authorities, local authorities, public bodies; derogations in cases of benefits for various commissions etc. In Croatia, cases where the obligation of tax secrecy is not violated are not numerous and mainly include standard solutions (a written consent of the persons concerned) or could be justified on the grounds of administrative efficiency (e.g. cooperation with other public bodies, or ad- 
ministrative cooperation in the field of taxes). However, some of these cases are prescribed very generally. ${ }^{11}$

\subsection{Tax Publicity}

For the purposes of this article, tax publicity could be defined as a framework in which tax authorities disclose and publicise tax information, (mainly) with the purpose of improving fiscal "discipline," reinforcing (social) values and thus supporting and increasing (voluntary) tax compliance. Such a framework aims to provoke shame in (delinquent) taxpayers as well as to strengthen public disapproval of and pressure on non-compliant behaviour. In that context, it is used primarily in two areas: as an additional tool in tax enforcement area and/or as a measure of fight against tax avoidance and tax evasion. This includes various stigma policies, e.g. publicising tax debtors' names. Therefore, they are also called "shaming penalties". However, little is known, especially in terms of empirical evidence, about the real effect of these shaming lists on reducing tax delinquency (Perez-Truglia, 2015). It could even have an opposite, contagious effect, due to possibility of taxpayers' conditional cooperation, i.e. they will not comply with their obligations if they perceive that other taxpayers do not comply too (Blaufus, Bob, Otto, 2014). Another issue is what kind of (delinquent) taxpayers would actually be the best target for the tax publicity model? It is hard(er) to believe that shame and paying-taxes-as-civic-virtue policies would have influence on those taxpayers who are generally more prone to (aggressive) avoidance of their tax obligations (Rogić Lugarić 2015; Perez Truglia \& Torano 2015).

The concept of tax publicity is applied in three systems analysed here - the U.S., Croatian and French - however, as we will see, the concept has different meanings in these systems. In France, tax publicity, introduced in 1984, means that there are lists of taxpayers of income and corporate tax, which are kept by the local administration. These lists are, under certain conditions, accessible to all taxpayers residing in the municipality (CGI, section L. 111). For taxpayers of income tax, it contains information on the number of family members, taxable income and the amount of income tax. These lists also contain information about persons who are not taxpayers but are resident in the municipality. Disclosure of any information contained in the lists is forbidden and punishable with a fine equal to the amount of taxes divulged (CGI, article 1762). Introduction of the lists was harshly criticised; the main argument being the possibility of their misuse and that they do not comply with the principle of protecting individual privacy and security. However, as Sid Ahmed (2007, p. 233) put it, the State Council did not respond precisely to that issue and therefore a chance for a debate on the real meaning and place of tax secrecy in French law has been missed. In Croatia, tax publicity in the form of making public a list of tax debtors or a shaming list was introduced in 2012 (General Tax Act, Article 8, Subsections 7-9). The shaming list comprises a list of taxpayers who owe the state specific amounts of unpaid taxes specified

11 E.g. if the data are disclosed for the purpose of tax enforcement procedures (section 8 subsection 5 number 5 General Tax Code), which might actually be a number of cases. 
by law ${ }^{12}$; the threshold of tax debt determining the place on the list varies depending on whether the taxpayer is a natural or a legal person. ${ }^{13}$ The list can be found on the revenue authority's website and includes the taxpayer's name and surname, year of birth, place of residence and the amount of his tax debt. If a person requesting information proves his legal interest, revenue authorities may add other information necessary for establishing the taxpayer's identity as well as disclose information on measures taken for tax recovery procedure. However, it does not contain information on the taxpayers whose tax debts are deferred or the taxpayers who reached an agreement on tax payment with revenue authorities. The list was supposed to be updated every three months. According to preparatory work, the main goal of the tax debtor list was to promote financial discipline, improve revenue authorities' efficiency in the area of tax enforcement, and raise society's awareness about the importance of voluntary tax compliance. It is worth noting that the introduction of the shaming list in the Croatian system in 2012 represents a significant shift considering tax confidentiality legislation in force before this amendment. The severity of the legislative changes is visible in the fact that a tax debtor listed was not notified, prior to publication, of the revenue authorities' intention to include their name on the list (or at least there is no such legal obligation or practice). However, the Croatian solution seemed too "ambitious" from the beginning, bearing in mind its main features and goals. Actually, this fact might be one of the main reasons for its "failure" (s. Rogić Lugarić 2015). It was not quite clear whether tax secrecy should be more in the service of reinforcing social norms or a deterrent instrument preventing tax avoidance. And if we analyse the legal wording of the concept of tax secrecy on the whole (especially its above mentioned exception), the latter solution seems more probable. However, the question is whether this sole instrument is sufficient, especially bearing in mind a lack of other, complementary tax law instruments in the Croatian system that would "send out the same message" (e.g. general anti-avoidance rule). The latest data indicate a questionable success of the shaming list - interest in tax publicity has fallen sharply over the past few years (measured by the number of "clicks").

In the U.S. system, as mentioned, the use of shaming lists is generally not recommended as its (unwarranted) consequences may undermine taxpayers' confidence in the tax system. However, there is a practice of publicising tax debtors' names at the state level. Almost half of the states use this policy (Perez-Truglia, 2015; Blank, 2013) namely Maryland, Vermont ${ }^{14}$ New York ${ }^{15}$, Colorado ${ }^{16}$, South Carolina, Oregon ${ }^{17}$, New Jersey, North Carolina. ${ }^{18}$ When it

\footnotetext{
12 E.g. value added tax, income tax, corporate tax etc. Local taxes are not included.

13 For legal persons, tax debts should exceed 300,000 Croatian Kuna (approximately 40,000 Euros); for natural persons pursing self-employed activity tax debts should exceed 100,000 Kuna (approximately 10,000 Euros) and for all the other taxpayers tax debts should exceed 15,000 Kuna (approximately 2,000 Euros).

14 <http://tax.vermont.gov/research-and-reports/reports/delinquent-taxpayer-report>.

$15<$ https://www.tax.ny.gov/enforcement/warrants.htm>.

$16<$ <https://www.colorado.gov/pacific/tax/delinquent-taxpayers-lists>.

$17<$ <http://gov.oregonlive.com/taxes/delinquents/>.

18 <http://www.dor.state.nc.us/collect/QryMostWanted.pdf>.
} 
comes to these lists, certain common features can be observed. Most of them contain basic data - name and surname, the amount of the tax debt, the type of taxes. Furthermore, as a rule, tax debtors included on the list are notified by revenue authorities in advance about the intention to include their name in the list and аге given the opportunity to settle their debt or resolve outstanding debts prior to listing. This policy is fully in line with theoretical suggestions (Posner, 2000). Perez-Truglia \& Torano's field experiment in three US states showed that shaming penalties can increase tax revenues, but their desirability remained unclear from a social welfare perspective (Perez-Truglia, 2015). Other interesting findings are related to the limits of peer pressure - the effect of the shaming penalty was significant for individuals who owed smaller amounts than for those with higher debts.

\subsection{Exchange of Information}

The "big bang" of 2009 (Oberson 2015, p. 8) has marked the beginning of the new era in the notion of tax information secrecy and the start of the shift towards tax transparency of taxpayers' cross-border income. In tackling aggressive tax planning, harmful tax regimes and tax evasion, often caused by lack of information, countries can engage in tighter cooperation to increase the amount of information at their disposal. (Remeur 2015, p. 16) The increased flow of information brings some challenges regarding the protection of taxpayers' rights. (Debelva \& Mosquera 2017, p. 362) During the tax procedure, taxpayers are obliged to report, determine, compute and pay taxes. The globalization, and its consequence in tax procedure - the exchange of information, caused additional increase of their duties. As antipode to their obligations, taxpayers are also protected by rights, either through domestic legislation or internationally. Taxpayers' rights guarantee fair process in the exchange of information, privacy protection in the transfer of data and procedural rights. However, the scope of these rights differs dependant on the legal instruments on which the information exchange is based as well as the national legislation. The development of the exchange of information, and in particular, recent rapid acceptance of automatic exchange of information as the new global standard has brought about the issues of breaches of confidentiality, privacy, secrecy and abuse of data exchanged to the highlight of global tax policy agenda. (Oberson 2015, p. 209)

Transparency, according to Remeur (2015, p. 10) undermines tax avoidance schemes used by multinational companies via tax planning strategies, hence avoiding paying their fair share in taxes. Zucman (2015, p. 47) estimates that losses in fiscal revenues due to the existence of tax havens amount to about USD 200 billion each year. The assessment that 10\%-20\% of national tax revenues in developing countries comes from international tax transaction only adds to the significance of greater transparency (Campbell \& Comer Jones 2014, p.37). However, does this affect the tax secrecy? Is tax secrecy incompatible with tax transparency from a policy perspective (Barrios Altafulla, 2014, p. 425)? 
Tax transparency and confidentiality are not mutually excluding (Remeur 2015 , p. 1). The main question is how to achieve the balance between the right to know and the limits to this right. The good example, according to the author, is French Tax Procedure Act, which justifies exceptions with the public interest and stipulates international exchange of information as exception to the rule of secrecy. Another example can be found in Croatian legislation, where the General Tax Act stipulates international cooperation (i.e. exchange of information) as the case where tax secrecy remains unharmed. Taking into account all issues mentioned above, it might be more appropriate to address the issue of tax secrecy in information exchange procedures by analysing the achieved level of tax transparency, as in fact the two represent two sides of the same coin.

Exchange of information mostly occurs in three main forms: spontaneous, on request or automatic (Oberson 2015, p. 27). Information is exchanged on the basis of the legal instrument which provides legal basis for the exchange. Although there are many instruments based on which the tax relevant information is exchanged, the secrecy and transparency provisions of OECD Model, FATCA and CRS will be analysed in more details below. However, it is noteworthy to mention that international agreements do not offer specific protection of taxpayers' rights in that regard, so it remains on the domestic law to deal with this issue (Barrios Altafulla 2014, p. 426).

\subsubsection{OECD Model and Confidentiality Provisions}

The provisions on the exchange of information are set out by the Article 26 of the OECD Model and contain conditions and safeguards regarding secrecy and the use of data. According to the 2014 Model $^{19}$ the foreseeably relevant information which is exchanged must be treated as secret, applying the same rules as for the information obtained under domestic laws of the receiving state. The information may be disclosed only to persons or authorities dealing with the collection of taxes and prosecution in respect of taxes and those persons may use the information only for such purposes (OECD 2014a, p. 40). Such provision on confidentiality represents only relative duty of secrecy. The information should only be secret as is the information obtained under domestic laws of the requesting state (Debelva \& Mosquera 2017, p. 369). Schenk-Geers (2009, p. 134) finds that states in fighting tax fraud must be able to exchange confidential documents and still recognize tax secrecy as an essential determinant of constitutional state in relation to taxpayers. After transmitting information to requesting state, the supplying state is no longer in the position to fulfil its constitutional obligation - hence the obligation of secrecy is transferred to the receiving state.

The original OECD Model concept contained an absolute duty of confidentiality, requiring that the information exchanged to be treated secretly and not be disclosed to any person or authority other than those concerned with the assessment or collection of taxes which are subject to the Convention (De-

19 The 2017 amendments to the OECD Model did not relate to the Article 26. 
belva \& Mosquera 2017, p. 369). The 1977 and 2005 versions of OECD Model Convention brought further amendments to Article 26. The article refers to the secrecy legislation of the receiving state, it extends the persons and authorities entitled to access information. The information use was widened and it became possible to disclose them in court hearings, case law and criminal proceedings (Oberson 2015, p. 26). Schenk-Geers (2009, p. 140) emphasizes the supremacy of treaty provisions over domestic tax secrecy provisions. Therefore, even if so provided by national legislation, the disclosure of information to other persons than those listed in Article 26 is forbidden. However, the maintenance of secrecy and sanctions for not abiding to those rules is a matter of domestic law of the receiving state (Oberson 2015, p. 25).

A similar secrecy clause is contained in the Tax Information Exchange Agreements (TIEA), developed by the OECD Global Forum on Transparency and Exchange of Information with the purpose of exchanging information between OECD and other countries with tax havens regarding their residents' offshore activities. The information exchanged must be treated as confidential and disclosed only to persons or authorities dealing with the assessment or collection of taxes, enforcement, prosecution or appeals in relation to taxes covered by agreement. Confidentiality is an autonomous concept as it does not refer to the law of the requesting state. Additionally, the information may only be exchanged regarding taxes covered by the agreement and it does not include supervision authorities (Oberson 2015, p. 63).

\subsubsection{FATCA and CRS - New Standards of Automatic Exchange of Information}

The recent developments in tax transparency have brought about the supremacy of automatic exchange of information over other forms of exchange. Firstly, the specific system was developed by the US with the intention to leave no US taxpayers untaxed. The OECD's work followed, and lead to the broadly accepted new standard in automatic exchange of information - the Common Reporting Standard.

The US have a taxing system based on both citizenship and residence as grounds for imposing income tax. The citizenship-based taxation regime allows the US tax authorities to tax all US citizens and US resident aliens on worldwide income, not taking into account their residence. (Holm 2014, p. 454) The Foreign Account Tax Compliance Act (FATCA), passed in 2010, represents the framework for reciprocal financial information exchange between the United States and other countries. Its aim is to supress offshore tax evasion and increase federal tax revenues. In the FATCA system, the taxpayers are required to report their international bank accounts (i.e. balances, receipts and withdrawals). Foreign financial institutions are obliged to report information about their U.S. clients (about taxpayer accounts and foreign entities in which U.S. taxpayers hold substantial ownership) to the Internal Revenue Service (IRS). As direct reporting to the IRS has raised legal issues for 
some countries, IGAs (intergovernmental agreements) have been developed (Campbell \& Comer Jones 2014, p. 33). ${ }^{20}$

FATCA requires US withholding agents to withhold tax on certain payments to foreign financial institutions (FFIs) which do not comply with the reporting obligation to the IRS about their US accounts and payments to non-financial foreign entities (NFFEs) which do not provide information about their US owners to withholding agents (Gupta 2013, p. 226). FATCA's extraterritorial effect consists of the obligation of FFIs to enter into agreement with the IRS and to report either to the US IRS or tax authorities in their respective countries, in case that the country has signed an IGA with the US, about the US investors and account holders and non-financial foreign entity investors with substantial US owners (Gupta 2013, pp. 227-228). In case that the FFI does not report, any US payer must withhold 30\% of payment made to FFI (Holm 2014, p. 462).

Both IGA and Competent Authority Agreement (CAA), the documents necessary for the implementation of FATCA, draw upon the 1988 Convention on Mutual Administrative Assistance in Tax Matters, allowing automatic exchange of information. The IGA ${ }^{21}$ and $C A A^{22}$ contain provisions on confidentiality, data safeguards and limits to the use of the data. They refer to the corresponding provisions of the Convention and provide for no specific rules in that regard.

The Article 22 of the Convention sets out that information obtained under the Convention must be treated as secret and protected in the same manner as information obtained under the domestic law of requesting state, ensuring the protection of personal data, in accordance with the safeguards specified by the domestic law of supplying state. Such information may be disclosed only to persons or authorities conducting the assessment, collection or recovery of, the enforcement or prosecution in respect of, or the determination of appeals in relation to, taxes of that state, or the oversight of those processes.

After the introduction of FATCA, the OECD and G20 worked on developing a single global standard of automatic financial information exchange which resulted in Model Competent Authority Agreement and the Common Reporting Standard. (Hey \& Heilmeier 2016, p. 242)

The OECD's Global Standard is based on two components - the Model Competent Authority Agreement (CAA), a legal instrument providing for the automatic exchange of information between countries, and the Common Reporting Standard (CRS), which sets out requirements for reporting and due diligence regarding specific categories of financial accounts. CAA links CRS

20 Model 1 IGA is the only reciprocal model and it has been used as a template for the OECD's global standard for exchange of information. Model 2 was drafted for countries with strong tradition of privacy and banking secrecy (Somare \& Wöhrer 2014, pp. 396-397).

21 E.g. Agreement between the Government of the Republic of Croatia and the Government of the United States of America to improve international tax compliance and to implement FATCA, Official gazette No. 5/2016.

22 E.g. CAA between the competent authorities of the United States of America and the Republic of Croatia, available at <https://www.porezna-uprava.hr/Dokumenti vijesti/FATCA Agreement_20032015.pdf>. 
with the legal basis for exchange of information between countries (Gadžo \& Klemenčić 2017, p. 215). The CRS provides financial firms with the template for due diligence, definitions, identification of foreign account holders and foreign controlling persons, to enable preparation for the exchange. On the other hand, Model CAA provides the governments with the legal basis, i.e. the framework for competent authority agreements. (McGill 2016, p. 2)

The obligation of participating jurisdictions is to annually exchange information they obtained from financial institutions with other competent authorities on an automatic basis. Unlike FATCA, there are no withholding sanctions for non-participating entities, but on the other hand, there is a monitoring mechanism entrusted with the Global Forum (Radcliffe 2014, p. 162; Oberson 2015, pp. 199-201). OECD (2014c, p. 13) suggested establishing automatic exchange relationship based on a multilateral instrument, such as the Multilateral Convention on Mutual Administrative Assistance in Tax Matters. The CRS requirements need to be implemented into the national legislations of participating jurisdictions. (Gadžo \& Klemenčić 2017, p. 217)

In accordance with the Model Competent Agreement, rules on confidentiality and the proper use of information will be based on a corresponding instrument which allows automatic exchange of information (Multilateral Convention or a bilateral tax treaty) containing provisions on the confidentiality of information exchanged and limiting the scope of persons entitled to access the information as well as the purpose for which the information may be used. (OECD 2014c, p. 13) Prior to entering into automatic information exchange agreement with another jurisdiction, the receiving jurisdiction must have legal framework and administrative capacity and processes in place which ensure confidentiality of information received and the use of information only for specified purposes (OECD 2014b, p. 8).

\section{Discussion and Conclusion}

The analysis in the article brings several conclusions. The systems analysed have been converging with respect to two facts: special treatment of tax information, and its exceptions. It seems that there is (general) recognition that tax information can be very sensitive and that personal information and its special treatment is secured by the legal institute of tax secrecy. However, the exact position of this institute depends on the overall approach and understanding of the role of (tax) information. It might be (primarily) understood as an essential element of protection of taxpayers' private lives or as means of monitoring the public authorities' work and performance. Therefore, as we have seen, tax secrecy might function as a rule (in the U.S., Croatian, French and German systems) or as an exception (the Swedish system). Where tax secrecy functions as a rule, which is still a prevailing concept, tax information is secret per se; exceptions are thoroughly prescribed by law and should be interpreted very strictly. Differences in the extent of tax secrecy can also be observed: while in certain systems tax secrecy concerns the framework for revenue authorities' use and disclosure of tax information when conducting 
tax procedures, in other systems it also concerns the secrecy of tax return or is even part of a broader framework that also includes access to public documents. Historical, as well as broader social context, determinants are obvious.

Another common feature is its, direct or indirect, influence on tax compliance. Direct influence is especially emphasised in the U.S. and German systems where tax secrecy is considered an important standard/principle in tax procedures, whose aim is to create a climate of confidence and trust between revenue authorities and taxpayers and thus support and encourage taxpayers' cooperation and voluntary tax compliance. In the Swedish case, a balance between tax secrecy and tax transparency seems to have the same role. Therefore, in the U.S., German and Swedish systems, tax confidentiality (and tax transparency) legislation is rather designed with the purpose of nurturing trust in the system and enhancing communication between the parties and thus it is closer to the so-called norm-based compliance model. In the Croatian system, however, the key role in influencing voluntary tax compliance is given to tax secrecy exceptions, where a deterrent effect is emphasised.

Tax secrecy has a double role - it functions as one of the main taxpayers' rights but also as the revenue authorities' tool when administering taxes, which was actually one of its first roles. The latter feature is especially visible in its exceptions. We identified three main exceptions: public interest (and common welfare); (strategic) tax publicity; exchange of information. As we have seen, a number of derogations in all the systems analysed could be justified on the grounds of public interest. Their primary intention is to facilitate revenue authorities' work and increase their efficiency in tax procedures as well as support their fiscal role. Two other exceptions, however, have additional goals.

Tax publicity is an instrument having a strong behavioural-change dimension and multiple goals. Although its implementation has recently become quite popular, there is no firm empirical evidence about its real effects. As we have seen in our analysis, it has different meanings. In the French system, its role is not quite clear. It is possible that it rather undermines the meaning of tax secrecy within a system promoting certain taxpayers' behaviour or serving as a "monitoring" tool. In the Croatian and U.S. systems, tax publicity is primarily seen as an instrument of deterrence but it might end up producing different results. While empirical research in the U.S. environment shows certain positive effects of this measure, it seems that in the Croatian system this measure has not met desired expectations. It is worth noting that the introduction of the shaming list in the Croatian system in 2012 represents a significant shift considering tax confidentiality legislation in force before this amendment. It would be very interesting to explore whether this measure in Croatia has actually produced the contagion effect.

The international aspect of tax secrecy, or more accurately tax transparency, relates to the exchange of information. To properly determine tax liabilities and achieve equality in taxation countries must rely, apart on national procedures of collecting information, also on international cooperation and assistance. In those procedures, sensitive financial taxpayers' information is no 
longer protected by the tax secrecy rules of one country, but is entrusted to other countries under confidentiality framework of international agreements and their own tax legislation. Due to the recent development of automatic information exchange, new concerns have surfaced, stressing the importance of keeping the information secret and prescribing purposes and persons authorized to us it. Although the information leaves the oversight and the protection of one revenue authority, its use by another authority must not jeopardize the confidentiality thereof.

So, to conclude, is there a balance of tax secrecy and its limitations? We would say that there is no perfect balance but obviously every legal system struggles to getting closer to this goal. However, in order to provide a more elaborate response to this question, one must dig deeper and take into consideration specific features of legal instruments and their implementation in countries with various traditions and legal concepts. Even recent normative developments have pointed out the everlasting search for this perfect balance. 


\section{References}

Barrios Altafulla, L.C. (2014). The Line between Tax Secrecy and Tax Transparency. In R. Petruzzi and K. Spies, eds., Tax Policy Challenges in the $21^{\text {st }}$ Century. Wien: Linde.

Bentley, D. (2007). Taxpayers' Rights: Theory, Origin and Implementation, Alphen aan den Rijn, the Netherlands: Kluwer Law International.

Blank, J. (2013). United States of America. In E. Kristofferson, M. Lang, Pistone, P. et al., eds., Tax Secrecy and Tax Transparency. Frankfurt am Main: Peter Verlag GMBH.

Blaufus, K., Bob, J. and Otto, P.E. (2014). The Effect of Tax Privacy on Tax Compliance - An Experimental Investigation. arqus Discussion Paper No. 164. At <http://www.arqus.info/mobile/paper/arqus_164.pdf>, accessed 3 August 2017.

Campbell, L. and Comer Jones, L. (2014). Automatic Information Exchange and Enhanced Transparency: Working toward a Solution for a Global Compliance Problem. The CPA Journal, (October), pp. 32-37.

Debelva, F. and Mosquera, I. (2017). Privacy and Confidentiality in Exchange of Information Procedures: Some Uncertainties, Many Issues, but Few Solutions. Intertax, 45(5), 362-381.

Department of the treasury (2000). Report to The Congress on Scope and Use of Taxpayer Confidentiality and Disclosure Provisions, Washington D.C. At <https://www.treasury.gov/resource-center/tax-policy/Documents/Report-Taxpayer-Confidentiality-2010.pdf>, accessed 3 August 2017.

Dubut, T. (2013). France. In E. Kristofferson, M. Lang, Pistone, P. et al., eds.,. Tax Secrecy and Tax Transparency: The Relevance of Confidentiality in Tax Law, Frankfurt am Main: PL Academic Research.

European Commission (2016). Guidelines for a Model for European Taxpayers Code. At <https://ec.europa.eu/taxation_customs/sites/taxation/files/guidelines_for_a_model_for_a_european_taxpayers_code_en.pdf > , accessed 7 June 2016 .

Gadžo, S. and Klemenčić, I. (2017). Effective international information exchange as a key element of modern tax systems: promises and pitfalls of the OECD's common reporting standard. Public Sector Economics, 41(2), 207-226.

Gupta, A. (2013). The Foreign Account Tax Compliance Act (FATCA). In O.-C. Günther and N. Tüchler, eds. Exchange of Information for Tax Purposes. Wien: Linde Verlag, 221-239.

Hambre, A. (2015). Tax Confidentiality: a Comparative Study and Impact Assessment of Global Interest, Örebro, Sweden: Örebro university.

Hey, J. and Heilmeier, R. (2016). Transparency: Common Standard - Cultural and Legal Differences. In H. D. Rosenbloom, ed. ITP @ 20. New York University School of Law, 556.

Holm, A.R. (2014). Extraterritorial Taxation in the Design of United States Tax Policy: Citizenship-Based Taxation and the Foreign Account Tax Compliance Act. In R. Petruzzi \& K. Spies, eds. Tax Policy Challenges in the $21^{\text {st }}$ Century. Wien: Linde Verlag, 447-470.

Huang, X. (2018). Ensuring Taxpayer Rights in the Era of Automatic Exchange of Information: EU Data Protection Rules and Cases. Intertax, 46(3), 225-239.

Kristoffersson, E., Persson, A.H., Nergelius, J., Valguarnera, F., Hambre A. and Larsson, Y. (2013). Sweden. In In E. Kristofferson, M. Lang, Pistone, P. et al., 
eds., Tax Secrecy and Tax Transparency: The Relevance of Confidentiality in Tax Law, Frankfurt am Main: PL Academic Research.

Kristofferson, E., Lang, M., Pistone, P., Schuch, J., Staringer, C. and Storck, A. (eds.) (2013). Tax Secrecy and Tax Transparency: The Relevance of Confidentiality in Tax Law, Frankfurt am Main: PL Academic Research.

Laury, S. and Wallace, S. (2005). Confidentiality and Taxpayer Compliance. National Tax Journal, 58(3), 427-438.

McGill, R. (2016). GATCA: The Globalization of Anti-Tax Evasion Frameworks. Derivatives and Financial Instruments, 18(3).

Ministry of Justice (2009). Public Access to Information and Secrecy Act. At <http://www.government.se/49b75b/contentassets/2ca7601373824c8395fc1f38516e6e03/public-access-to-information-and-secrecy-act>, accessed 10 June 2017.

Nergelius, J. (2017). Secrecy and Transparency in the Tax Administration. At <https://taxpayerrightsconference.com/wp-content/uploads/2016/08/ Nergelius_Final_Paper.pdf>, accessed 10 June 2017.

Oberson, X. (2015). International Exchange of Information in Tax Matters: Towards Global Transparency, Cheltenham, UK; Northampton, MA, USA: Edward Elgar publishing.

OECD (2003). Taxpayers' Right and Obligation - Practice Note, Paris: OECD Publishing. At <https://www.oecd.org/tax/administration/Taxpayers'_Rights_ and_Obligations-Practice_Note.pdf>, accessed 7 June 2016.

OECD (2012). Keeping It Safe: The OECD Guide on the Protection of Confidentiality of Information Exchanged for Tax Purposes, Paris: OECD Publishing.

OECD (2014a). Model Convention with Respect to Taxes on Income and on Capital, OECD.

OECD (2014b). Standard for Automatic Exchange of Financial Account Information: Common Reporting Standard, Paris: OECD Publishing.

OECD (2014c). Standard for Automatic Exchange of Financial Account Information in tax Matters, Paris: OECD Publishing.

Perez-Truglia, R. (2015). Should we publicly shame delinquent taxpayers? World Economic Forum, 20 March 2015. At <https://www.weforum.org/agenda/2015/03/should-we-publicly-shame-delinquent-taxpayers/>, accessed 5 June 2017.

Perez-Truglia, R. and Troiano, U. (2015). Shaming Tax Delinquencies. Theory and Evidence from a Field Experience in the United States. At <https://papers. ssrn.com/sol3/papers.cfm?abstract_id=2558115>, accessed 5 June 2017.

Posner, E. (2000). Law and Social Norms: The Case of Tax Compliance. Virginia Law Review, 86, 1781-1819.

Radcliffe, P. (2014). The OECD's Common Reporting Standard: The Next Stop in the Global Fight against Tax Evasion. Derivatives and Financial Instruments, 16(4), 160-169.

Remeur, C. (2015). Tax transparency: Openness, disclosure and exchange of information. At <http://www.europarl.europa.eu/RegData/etudes/ IDAN/2015/565902/EPRS_IDA(2015)565902_EN.pdf>, accessed 10 April 2018.

Rogić Lugarić, T. (2015). Porezna tajna: sigurnost prošlosti, sjena budućnosti. Hrvatska i komparativna javna uprava, 15(4), 815-846. 
Schenk-Geers, T. (2009). International Exchange of Information and the Protection of Taxpayers EUCOTAX Se. P. H. J. Essers, E. Kemmeren, \& M. Lang, eds., Alphen aan den Rijn: Kluwer Law Intrnational.

Schwartz, P. (2008). The Future of Tax Privacy. National Tax Journal LXI(4) Part 2: 883-900

Sid Ahmed, K. (2007). Droits fondamentaux du contribuable et procédures fiscales. Paris: L'Harmattan

Somare, M. \& Wöhrer, V. (2014). Two Different FATCA Model Intergovernmental Agreements: Which Is Preferable? Bulletin for International Taxation, 68(8), 395-403.

Tipke, K., J. Lang (2010). Steuerrecht. Köln: Verlag Dr. Otto Schmidt.

Valta, M. (2013). Germany. In Kristofferson, E., Lang, M., Pistone, P., Schuch, J., Staringer, C., Storck, A., eds. Tax Secrecy and Tax Transparency: The Relevance of Confidentiality in Tax Law, Frankfurt am Main: PL Academic Research.

Zucman, G. (2015). The Hidden Wealth of Nations: The Scourge of Tax Havens. Chicago and London: The University of Chicago Press. 